\title{
Dermatophytoses in patients attended from a private clinical analysis laboratory in João Pessoa-PB, between 2015 to 2019
}

\author{
Dermatofitoses em pacientes atendidos em um laboratório privado de João Pessoa-PB, \\ entre 2015 a 2019
}

Francisco Patrício de Andrade Júnior ${ }^{1 *}$, Laísa Vilar Cordeiro², Edeltrudes de Oliveira Lima ${ }^{3}$

\begin{abstract}
${ }^{1}$ Farmacêutico pela Universidade Federal de Campina Grande (UFCG), Mestre e Doutorando pelo Programa de Pósgraduação em Produtos Naturais e Sintéticos Bioativos da Universidade Federal da Paraíba (UFPB); ${ }^{2}$ Farmacêutica pela UFPB, Especialista em Atenção Farmacêutica e Farmácia Clínica, Mestra em Biologia Celular e Molecular pelo Programa de Pós-graduação em Biologia Celular e Molecular (UFPB), Doutoranda pelo Programa de Pós-graduação em Produtos Naturais e Sintéticos Bioativos (UFPB); ${ }^{3}$ Doutora em Farmácia pela Universidade de São Paulo (USP), Professora Associada do Departamento de Ciências Farmacêuticas e do Programa de Pós-Graduação em Produtos Naturais e Sintéticos Bioativos (UFPB)
\end{abstract}

\begin{abstract}
Introduction: dermatophytoses or "tineas" are characterized by being mycoses caused by fungi of the genera Epidermophyton, Trichophyton and Microsporum. These mycotic infections can present themselves as a form of lesions that affect the skin, hair and nails of individuals of both genders and all ages. Objective: to elucidate the epidemiological profile of dermatophytoses in patients examined by a private clinical analysis laboratory in João Pessoa-PB, between 2015 and 2019. Methodology: this is an epidemiological, analytical, retrospective and documentary study, in which data collection took place at the Clinical Pathology Laboratory - "HEMATO", located in João Pessoa - PB. Results: the profile of those affected was predominantly female (58.5\%), 18 to 59 years old (38.4\%), white (53.6\%) and with lesions, mainly in skin glabrous (38.5\%), feet (33.3\%) and nails (12.8\%). When relating the age group to the injury site, it was noticed that injuries on glabrous skin, feet and nails, were more frequent in individuals aged 18 to 59 years, while injuries to the scalp were mostly found in individuals younger than 18 years old. The most prevalent species were M. canis (31.9\%) and T.rubrum (31.9\%). When correlating the fungal species with the lesion site, it was noted that M. canis was the main agent responsible for lesions in glabrous skin, scalp and hands, while T. rubrum was predominantly observed in nails and T. mentagrophytes in feet. Conclusion: it is concluded that the data present in this research can promote the development of indicators and public policies for the population most susceptible to dermatophytosis.
\end{abstract}

Keywords: Dermatophytes. Tinea. Filamentous Fungi.

\begin{abstract}
Resumo
Introdução: dermatofitoses ou tineas se caracterizam por serem micoses causadas por fungos dos gêneros Epidermophyton, Trichophyton e Microsporum. Essas infeç̧ões micóticas podem se apresentar na forma de lesões que acometem pele, pelo e unhas de indivíduos de ambos os gêneros e todas as idades. Objetivo: elucidar o perfil epidemiológico de dermatofitoses de pacientes atendidos por um laboratório privado de análises clínicas em João Pessoa-PB, entre 2015 a 2019. Metodologia: trata-se de um estudo epidemiológico, analítico, retrospectivo e documental, em que a coleta de dados ocorreu no Laboratório de Patologia Clínica - HEMATO, localizado em João Pessoa - PB. Resultados: o perfil de acometidos foi predominantemente de indivíduos do sexo feminino $(58,5 \%)$, com 18 a 59 anos de idade $(38,4 \%)$, brancos $(53,6 \%)$ e com lesões, principalmente, em pele glabra $(38,5 \%)$, pés $(33,3 \%)$ e unhas $(12,8 \%)$. Ao relacionar a faixa etária com o local da lesão, percebeu-se que lesões em pele glabra, pés e unhas, foram mais frequentes em indivíduos de 18 a 59 anos, enquanto que lesões no couro cabeludo foram majoritariamente encontradas em indivíduos menos de 18 anos. As espécies mais prevalentes foram M. canis (31,9\%) e T. rubrum (31,9\%). Ao correlacionar a espécie fúngica com o local da lesão, notou-se que $M$. canis foi o principal agente responsável por lesões em pele glabra, couro cabeludo e mãos, enquanto T. rubrum foi predominantemente observado em unhas e T. mentagrophytes em pés. Conclusão: os dados obtidos nesta pesquisa podem fomentar o desenvolvimento de indicadores e políticas públicas para a população mais susceptível às dermatofitoses.

Palavras-chave: Dermatófitos. Tinea. Fungos Filamentosos.
\end{abstract}

\section{INTRODUCTION}

Fungi are single-celled (yeast-like) or pluricellular (filamentous) microorganisms, ubiquitous and causing various

Correspondente/Corresponding: *Francisco Patricio de Andrade Júnior - End: Rua Tab. Stanislau Eloy, 41 - Conj. Pres. Castelo Branco III, João Pessoa - PB, CEP: 58050-585. - Tel: 55 (84)98135-7242 - E-mail: juniorfarmacia.ufcg@outlook.com diseases, such as allergies, mycotoxicoses and mycoses, in which the latter can be classified into: superficial, subcutaneous or systemic mycosis (ANDRADE JÚNIOR et al., 2018; NÓBREGA JÚNIOR et al., 2018; SILVA; MALTA, 2016).

Dermatophytoses or tineas, in turn, are superficial mycotic and zoonotic infections, caused by fungi of the genus Epidermophyton, Trichophyton and Microsporum, 
commonly called dermatophytes (LANA et al., 2016; ILYAS; SHARMA, 2017; PERES et al., 2010).

These fungi are filamentous, keratinolytic and keratinophilic, being, therefore, capable of parasitizing skin, hair and nails, in which the form of contamination can be anthropophilic, zoophilic or geophilic (ILYAS; SHARMA, 2017; LANA et al., 2016; MEDEIROS; CREPALDI; TOGNOLI, 2009; PERES et al., 2010).

In order to have an infectious process in humans, dermatophytes first adhere to the stratum corneum, which has an acidic $\mathrm{pH}$. Then, there is the release of acidic proteases and keratinases, which will allow to cleave and metabolize proteins, with the microenvironment becoming alkalized. This change in $\mathrm{pH}$ causes the production of alkaline proteases and keratinases that will once again cause protein cleavage and metabolization, allowing fungal nutrition and the development of hyphae and arthroconidia. This results in a successful invasion of the stratum corneum and the beginning of the infectious process (ANDRADE JÚNIOR et al., 2020; PERES et al., 2010).

From an immunological point of view, there is the recognition of molecules present in the fungal wall, mainly 6-(1,3)-glycans. These carbohydrates are recognized by dectin-1, dectin-2 and Toll-like receptors (TLR) type 2 and 4, causing activation of the nuclear factor kappa B (NF-KB) pathway, allowing the production of pro-cytokines. inflammatory diseases, such as IL-1, IL-6 and TNF- $\alpha$ (ANDRADE JÚNIOR et al., 2020; LIU et al., 2017).

Once the tissue is parasitized by a dermatophyte, the type of tinea can be classified according to its anatomical location in: tinea capitis (scalp), tinea pedis (foot), tinea corporis (body), tinea cruris (inguinal region) e tinea unguium (nails) (LANA et al., 2016).

The affected individual usually presents lesions, flaking and itching, however the clinical signs and symptoms is not the only parameter that must be analyzed, since it is important to identify the genus or species for the development of a more appropriate pharmacotherapy. Thus, laboratory diagnosis is essential and is performed mainly through microscopy using potassium hydroxide (KOH) to elucidate fungal structures. (LANA et al., 2016).

Pharmacological treatment can be carried out using allylamines, azoles and griseofulvin. However, preventive measures are essential, such as good personal hygiene and the use of appropriate clothing in changing rooms, gyms and swimming pools (LANA et al., 2016; NENOFF et al., 2014; SOCIEDADE BRASILEIRA DE DERMATOLOGIA, 2017).

T. rubrum is the most prevalent species, being responsible for up to $70 \%$ of dermatophytoses, especially onychomycosis. T. mentagrophytes, in turn, is the second most commonly observed dermatophyte. $M$. canis, on the other hand, causes about 15\% of dermatophyte infections, the most detected in the scalp, in states such as Rio de Janeiro, Rio Grande do Sul, Espírito Santos and São Paulo (LANA et al., 2016, KHALED et al., 2015;). However, the prevalence of dermatophytoses caused by different species can vary according to geographic location, climate, age group and tourism (LANA et al., 2016).
Thus, it is important to develop epidemiological studies to better characterize different populations, especially in places where there is a shortage of current research, such as João Pessoa-PB.

Given the above, the present study aimed to elucidate the epidemiological profile of dermatophytoses in patients examined by a private clinical analysis laboratory in João Pessoa-PB, between 2015 and 2019.

\section{METHODOLOGY}

\section{Study classification}

It was an epidemiological, descriptive, retrospective and analytical study (HOCHMAN et al., 2005), in which an investigation was carried out about the epidemiological profile in individuals with clinical suspicion for dermatophytosis, between the years 2015 to 2019, examined at the Clinical Pathology Laboratory - HEMATO, João Pessoa-PB. The study was approved by the Research Ethics Committee of the Health Sciences Center, UFPB, with the approval number: $3,770,492$.

\section{Data collect}

Data collection took place between December 2019 and January 2020. These are secondary data from mycological tests that were present in the database of the Clinical Pathology Laboratory - HEMATO.

\section{Sample inclusion and exclusion criteria}

The results of the reports of the mycological examinations carried out between January 2015 and December 2019 were included, which were fully completed and which presented as identified etiologic agents, members of the genera Epidermophyton, Trichophyton and / or Microsporum. Reports that were incomplete, strikethrough, that were outside the stipulated period or that had fungi of other genera, as etiological agents, were excluded.

\section{Statistical analysis of epidemiological data}

The data were analyzed using the Statistical Package for Social Science (SPSS) software, version 13.0. The calculation of simple and absolute frequency was performed for the variables gender, ethnicity, age group, location of the lesion and species. In addition, the gender was associated with age, ethnicity and location of the injury, the location of the injury with the age group and the location of the injury with the species. The Chi-Square test was applied and associations were considered statistically significant when $p<0.05$ for the rejection of nullity hypotheses.

\section{RESULTS}

Between the years 2015 to 2019, 1055 suspected mycoses were analyzed, however, there were only 94 cases of dermatophytosis with a predominance of female patients (Figure 1). 
Figure 1 - Percentage of gender affected by dermatophytes in João Pessoa-PB, between the years 2015 to 2019.

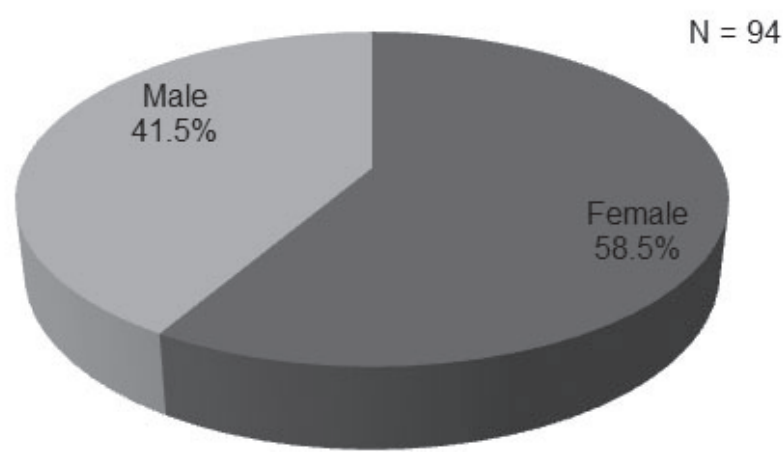

Source: Own authorship

Table 1 shows the statistical association between gender and the personal and clinical data of people affected by dermatophytes.

Tabela 1 - Statistical association between gender and the personal and clinical data of people affected by dermatophytes in João Pessoa - PB between the years 2015 to 2019.

\begin{tabular}{|c|c|c|c|c|c|}
\hline \multirow{2}{*}{ Personal and clinical data } & \multicolumn{2}{|c|}{ Female } & \multicolumn{2}{|c|}{ Male } & \multirow[t]{2}{*}{$p$} \\
\hline & $\mathbf{N}$ & $\%$ & $\mathbf{N}$ & $\%$ & \\
\hline \multicolumn{6}{|l|}{ Age range } \\
\hline 0 to 17 years & 09 & 16.4 & 12 & 30.8 & \\
\hline 18 to 59 years & 33 & 60.0 & 15 & 38.4 & 0,099 \\
\hline From 60 years & 13 & 23.6 & 12 & 30.8 & \\
\hline Total & 55 & 100 & 39 & 100 & \\
\hline \multicolumn{6}{|l|}{ Ethnicity } \\
\hline White & 29 & 52.7 & 21 & 53.8 & \\
\hline Mulatto & 25 & 45.5 & 18 & 46.2 & * \\
\hline Black & 01 & 1.8 & 00 & 0.0 & \\
\hline Total & 55 & 100 & 39 & 100 & \\
\hline \multicolumn{6}{|l|}{ Injury site } \\
\hline Foot & 15 & 27.3 & 13 & 33.3 & \\
\hline Glabrous skin & 18 & 32.7 & 15 & 38.5 & \\
\hline Scalp & 10 & 18.2 & 03 & 7.7 & * \\
\hline Nails & 12 & 21.8 & 05 & 12.8 & \\
\hline Hands & 00 & 0.0 & 03 & 7.7 & \\
\hline Total & 55 & 100 & 39 & 100 & \\
\hline
\end{tabular}

p-Chi-Square Test; * Inapplicability of the Chi-Square test.

Source: Research data, 2020.

Table 2 shows the association between the injury site and age group.
Table 2-Association between the injury site and the age group of people affected by dermatophytoses in João Pessoa - PB between the years 2015 to 2019.

\begin{tabular}{|c|c|c|c|c|c|c|}
\hline \multirow[t]{2}{*}{ Injury site } & \multicolumn{2}{|c|}{$\begin{array}{c}0 \text { to } 17 \\
\text { years old }\end{array}$} & \multicolumn{2}{|c|}{$\begin{array}{c}18 \text { to } 59 \\
\text { years old }\end{array}$} & \multicolumn{2}{|c|}{$\begin{array}{c}\text { From } 60 \\
\text { years }\end{array}$} \\
\hline & $\mathbf{N}$ & $\%$ & $\mathbf{N}$ & $\%$ & $\mathbf{N}$ & $\%$ \\
\hline Foot & 02 & 9.5 & 14 & 29.2 & 12 & 48.0 \\
\hline Glabrous skin & 10 & 47.6 & 18 & 37.5 & 05 & 20.0 \\
\hline Scalp & 07 & 33.3 & 05 & 10.4 & 01 & 4.0 \\
\hline Nails & 01 & 4.8 & 10 & 20.8 & 06 & 24.0 \\
\hline Hands & 01 & 4.8 & 01 & 2.1 & 01 & 4.0 \\
\hline Total & 21 & 100 & 48 & 100 & 25 & 100 \\
\hline
\end{tabular}

Source: Research data, 2020.

Then, it is possible to observe the percentage of dermatophytes identified.

Figura 2 - Percentage of different species of dermatophytes identified in affected by dermatifitoses in a private laboratory in João Pessoa - PB, between the years 2015 to 2019.

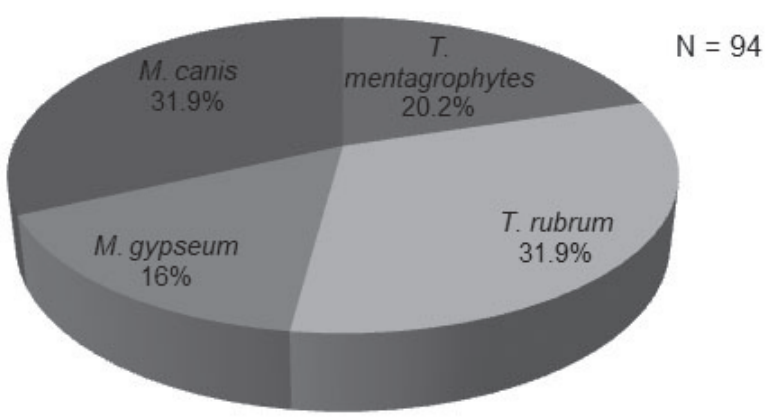

Source: Own authorship

Table 3 shows the association between the fungal species and the injured site.

Table 3-Association between the species of dermatophytes and the injured site of people affected by dermatophytoses in João Pessoa-PB between the years 2015 to 2019.

\begin{tabular}{lccccccccr}
\hline Injury site & M. canis & \multicolumn{3}{c}{ M. } & T. rubrum & \multicolumn{2}{c}{$\begin{array}{c}\text { T. } \\
\text { mentagrophytes }\end{array}$} \\
& \multicolumn{1}{c}{ N } & \% & N & $\%$ & N & $\%$ & N & $\%$ \\
\hline Foot & 04 & 13.3 & 06 & 40.0 & 08 & 26.7 & 10 & 52.6 \\
Glabrous & 17 & 56.7 & 05 & 33.3 & 10 & 33.3 & 01 & 5.3 \\
skin & & & & & & & & \\
Scalp & 06 & 20.0 & 00 & 0.0 & 05 & 16.7 & 02 & 10.5 \\
Nails & 00 & 0.0 & 04 & 26.7 & 07 & 23.3 & 06 & 31.6 \\
Hands & 03 & 10.0 & 00 & 0.0 & 00 & 0.0 & 00 & 0.0 \\
\hline Total & 30 & 100 & 15 & 100 & 30 & 100 & 19 & 100 \\
\hline
\end{tabular}

Source: Research data, 2020.

\section{DISCUSSION}

The female gender was also predominant in other studies carried out in Brazil, such as Fortaleza-CE, where of 534 infected with dermatophytes $57.1 \%$ were female (BRILHANTE et al., 2000). In Amazonas, among 48 af- 
fected individuals, it was observed that $62 \%$ were female (CORTEZ et al., 2012). While in a research carried out in Recife- $P E$, the predominance for male individuals was evidenced (SILVA et al., 2018).

However, even though the female gender has presented itself as the most prevalent in this research, it is evident that the microorganisms that cause dermatophytoses do not show a gender predilection, making the development of these conditions to be associated with individual issues, such as cultural, environmental and hygienic characteristics. and immunological (SILVA et al., 2019).

Regarding the age group, for both genders, there was a predominance of individuals between 18 and 59 years of age. These results partially resemble a study carried out in Recife- $P E$, in which individuals between 31 and 60 years of age were the most prevalent for dermatophytes (SILVA et al., 2018). While in a research carried out in Cuité-PB, it was evidenced that the average age of people affected was 31.5 years of age, therefore there is a similarity with the results found (FIGUEIREDO et al., 2015).

The age group from 18 to 59 years is the one in which there is greater work activity, being generally associated with the use of closed shoes and possible contact with chemicals, skin attackers, in addition to more intense contact with other individuals, which can facilitate the development of dermatophytoses (OLIVEIRA et al., 2006; SILVA et al., 2018).

Regarding ethnicity, there was a greater number of cases, for both genders, in individuals considered white, which is similar to a study conducted in Cuité-PB (FIGUEIREDO et al., 2015). However, there is no correlation in the literature between human skin melanin and the occurrence of dermatophytoses.

Observations on the lesion site show that glabrous skin, followed by feet and nails, were the most prevalent for dermatophytes, in both genders, similar to a study conducted in Recife-PE (SILVA et al., 2018). Tinea corporis, generally affects the shoulders, trunk and arms and has been associated as one of the most commonly observed dermatophytes, due to the fact that in general dermatophytosis will start on glabrous skin, and may subsequently reach hair and hair follicles (LANA et al., 2016; PERES et al., 2010). On the other hand, the high prevalence for tinea pedis and tinea unguium, in this research, may be associated, mainly, with the excessive use of closed shoes, for the development of work and/or school activities (OLIVEIRA et al., 2006; SILVA et al., 2018).

In relation to tinea pedis, tinea unguium and tinea corporis, they were evidenced mainly in individuals between 18 and 59 years of age, who are those of working age. In individuals between 0 and 17 years of age, it is observed that there are lower prevalences related to injuries to the feet, nails and hands, and this can be justified due to the fact that children have lower concentrations of keratin in these sites, causing this population are less susceptible to keratinolytic fungi (SILVA et al., 2018). However, tinea capitis was mostly observed in this age group, similar to other studies (ARAÚJO et al., 2012; CORTEZ et al., 2012; FREITAS et al., 2008; SILVA et al., 2018). Thus, it is important to emphasize that children are within the risk group of developing tinea capitis, due to issues of immunological immaturity and the greater involvement with playful activities related to bathing areas, contact with soil and/or animals (JONH et al., 2018; LANA et al., 2016).

$M$. canis is considered a zoophilic species, so its high prevalence is related to contact with infected animals, especially dogs, cats and rodents (RODRIGUES et al., 2008; HAWKINS; SMIDT, 2014; SILVA et al., 2019), while the presence of $T$. rubrum, as one of the main agents of dermatophytosis, is also observed in other studies (FIGUEIREDO et al., 2015; SILVA et al., 2018).

The species $M$. canis was evidenced mainly in glabrous skin, followed by scalp and feet. In addition, when compared to the other dermatophytes found, M. canis was the main agent found in the scalp, which corroborates with other studies carried out in Rio de Janeiro, Rio Grande do Sul, Espírito Santos, São Paulo, Goiânia, Africa and the European continent (LANA et al., 2016; REBOLLO; LÓPEZ-BARCENAS; ARENAS, 2008; SCARAMPELLA et al., 2015).

M. gypseum was observed mostly in feet, followed by glabrous skin and nails. This was the species found less frequently in this research, which is similar to other studies (LANA et al., 2016; SILVA et al., 2018).

T. rubrum was mainly isolated in cases of tinea ungueal, tinea pedis and tinea corporis, which is justified due to the ability of these microorganisms to easily parasitize nails and skin (SILVA et al., 2018; SILVA et al., 2019). Although this species of dermatophyte is rarely able to invade the scalp (LANA et al., 2016), the presence of these fungi in this site was also observed in this study.

T. mentagrophytes was found mainly in nail and skin samples, being considered in the literature, together with T. rubrum, the main causes of tinea corporis. This microorganism is capable of infecting both humans and animals, making this pathogen more easily infect individuals who maintain greater contact with animals and/or who live in rural areas (HAWKINS; SMIDT, 2014; LANA et al., 2016).

Thus, it is evident that, in this research, $T$. rubrum and $M$. canis are the main pathogens associated with dermatophytoses. This information is especially relevant because, currently, the genus Trichophyton is considered the most important from a clinical and epidemiological point of view. However, the data presented show a possible change in this profile, since members of the Microsporum genus affected a large number of individuals and showed the ability to infect different anatomical sites.

\section{CONCLUSIONS}

Between 2015 and 2019, 1055 suspected superficial mycoses were analyzed in a private clinical analysis laboratory in João Pessoa-PB, however, only 94 cases of dermatophytosis were recorded. The predominant profile 
of affected individuals was the female gender, aged 18 to 59 years, white and with lesions mainly in glabrous skin, presenting the species $M$. canis and T. rubrum as the most prevalent etiological agents.

When associating the age group with the injury site, it was noticed that injuries on glabrous skin, feet and nails were predominant in individuals aged 18 to 59 years, while scalp injuries were mostly found in individuals under 18 years of age. When correlating the fungal species with the lesion site, it was noted that $M$. canis was the main agent responsible for damage to glabrous skin, scalp and hands, while T. rubrum was predominantly observed in nails and T. mentagrophytes in the feet.

In view of the above, the data presented in this research are important for public health, since they can contribute to the development of public policies that seek to support the most susceptible population.

\section{ACKNOWLEDGMENTS}

To the "Conselho Nacional de Desenvolvimento Científico e Tecnológico" (CNPq) for financial assistance and to the Clinical Pathology Laboratory - Hemato, for allowing access to mycological exams.

\section{REFERENCES}

ANDRADE JÚNIOR, F. P. et al. Alternaria spp. em alimentos: micotoxinas, danos celulares e possíveis riscos a saúde. Tchê Química, Nova Prata, v. 15, n.30, p. 19-26, 2018.

ANDRADE JÚNIOR, F. P. et al. Microsporum spp como causador de dermatofitoses: uma revisão. Research, Society and Development, Itabira, v.9, n.5, 2020

ARAÚJO, S. M. et al. Agentes fúngicos em diferentes locais anatômicos nos Serviços Públicos de Saúde em Cuiabá, Mato Grosso, Brasil. Revista do Instituto de Medicina Tropical de São Paulo, São Paulo, v.54, n.1, p.5-10, 2012.

BRILHANTE, R. S. N. et al. Epidemiology and ecology of dermatophytoses in the City of Fortaleza: Trichophyton tonsurans as important emerging pathogen of tinea capitis. Revista da Sociedade Brasileira de Medicina Tropical, Uberaba, v.33, n.5, p.417-425, 2000.

CORTEZ, A. C. et al. Frequency and a etiology of dermatophytosis in children age 12 and under in the state of Amazonas, Brazil. Revista Iberoamericana de Micología, Barcelona, v.29, n.4, p.223-226, 2012.

FIGUEIREDO, J. V. et al. Diagnóstico laboratorial de dermatofitoses no município de Cuité-PB, Brasil. Educação Ciência e Saúde, Cuité, v.2, n.2, p.49-63, 2015.

FREITAS, R. S. et al. Influence of the human activity in the Atlantic Forest and in the prevalence of etiological agents of dermatophytosis in a coastal city of Southern Brazil Ubatuba (São Paulo). International Journal Of Dermatology, Philadelphia, v.47, n.8, p.865-867, 2008.

HAWKINS, D. M.; SMIDT, A. C. Superficial fungal infections in Children. Pediatric Clinics of North America, Philadelphia, v. 61, n.2, p.443-455, 2014.
HOCHMAN, B.; NAHAS, F. X.; OLIVEIRA FILHO, R. S.; FERREIRA, L. M. Desenhos de pesquisa. Acta Cirurgica Brasileira, São Paulo, v.20, sup.2, p.2-9, 2005

ILYAS, M.; SHARMA, A. Cutaneous fungal infections in solid organ transplant recipients. Transplantation Reviews, Copenhagen, v.31, n.3, p.158-165, 2017.

JOHN, A.M.; SCHWARTZ, R.A.; JANNIGER, C.K. The kerion: an angry tinea capitis. International Journal of Dermatology, Philadelphia, v.57, v.1, p.3-9, 2018.

KHALED, J. M. et al. Dermatophyte and non dermatophyte fungi in Riyadh City, Saudi Arabia. Saudi Journal of Biological Sciences, [s.I], v.22,n.5, p.604-609, 2015.

LANA, D. F. D. et al. Dermatofitoses: agentes etiológicos, formas clínicas, terapêutica e novas perspectivas no tratamento. Clinical \& Biomedical Research, Porto Alegre, v.36, n.4, p.230-241, 2016.

LIU, T. et al. NF-KB signaling in inflammation. Signal Transduction and Target Therapy, [s.I.], v.2, 2017.

MEDEIROS, F.; CREPALDI, N.; TOGNOLI, L. Dermatófitos - revisão de literatura. Revista Científica Eletrônica de Medicina Veterinária, Garça, v.7, n.12, 2009.

NENOFF, P. et al. Mycology - an update. Part 1: Dermatomycoses: causative agents, epidemiology and pathogensis. Journal Der Deutschen Dermatologischen Gesellschaft, Berlin, v.12, n.3, p.188-210, 2014.

NÓBREGA JÚNIOR, A. C. C. et al. Microrganismos isolados de uroculturas em um hospital universitário do estado da Paraíba, Brasil. Educação, Ciência e Saúde, Cuité, v.5, n.1, p.15-30, 2018.

OLIVEIRA, J. A. A. et al. Micoses superficiais na cidade de Manaus, AM, entre março e novembro/2003. Anais Brasileiros de Dermatologia, Rio de Janeiro, v.81, n.3, p.238-243, 2006.

PERES, N. T. A. et al. Dermatófitos: interação patógeno-hospedeiro e resistência a antifúngicos. Anais Brasileiros de Dermatologia, Rio de Janeiro, v.85, n.5, p.657-667, 2010.

REBOLLO, N.; LÓPEZ-BARCENAS, A. P.; ARENAS, R. Tinea capitis. Actas dermo-sifiliográficas, Cidade do México, v.99, n.2, p.91-100, 2008.

RODRIGUES, G. S. et al. Tinea capitis em adulto por Trichophyton violaceum no Brasil: relato de um caso e revisão da literatura. Anais Brasileiros de Dermatologia, Rio de Janeiro, v.83, n.6, p.544-548, 2008.

SOCIEDADE BRASILEIRA DE DERMATOLOGIA (SBD). Dermatofitoses. 2017. Disponível em: https://www.sbd.org.br/dermatologia/unhas/ doencas-e-problemas/dermatofitose/91/. Acesso em: 03 ago. 2019.

SCARAMPELLA. F. et al. Dermoscopic features in 12 cats with dermatophytosis and in 12 cats with self-induced alopecia due to other causes: an observational descriptive study. Veterinary Dermatology, Oxford, v.26, n.4, p.282-286, 2015.

SILVA, C. J. A.; MALTA, D. J. N. A importância dos fungos na biotecnologia. Cadernos de Graduação - Ciências Biológicas e da Saúde, Recife, v. 2, n.3, p.49-66, 2016.

SILVA, C. S. et al. Etiologia e epidemiologia da tinea capitis: relato de série de casos e revisão da literatura. Revista Brasileira de Análises Clínicas, Rio de Janeiro, v.51, n.1, p.9-16, 2019.

SILVA, K. A. et al. Etiologia das dermatofitoses diagnosticadas em pacientes atendidos no laboratório de micologia médica do centro de biociências da Universidade Federal de Pernambuco, entre 2014-2017. Revista Brasileira de Análises Clínicas, Rio de Janeiro, v. 50, n.1, p.33-37, 2018.

Submetido em: 26/03/2020

Aceito em: 28/12/2020 